\title{
REVERSE TRANSCRIPTION LOOP-MEDIATED ISOTHERMAL AMPLIFICATION (RT-LAMP) FOR DETECTION OF COCONUT CADANG-CADANG VIROID (CCCVd) VARIANTS IN OIL PALM
}

\section{AHMAD ZAIRUN MADIHAH*; MOHAMED MAIZATUL-SURIZA* and ABU SEMAN IDRIS*}

\begin{abstract}
The coconut cadang-cadang viroid (CCCVd) is the causal agent of orange spotting (OS) disease in commercial oil palm (Elaeis guineensis) plantations in Malaysia. At present, the methods used to detect OS are time-consuming and can be inaccurate. Here, we describe the development of a rapid, sensitive and specific method of detecting CCCVd variants in oil palm leaves using a reverse transcription loop-mediated isothermal amplification (RT-LAMP) method. RT-LAMP detected CCCVd variants at a concentration of 2 $n g \mu l^{-1}$ in less than $1 \mathrm{hr}$ at $63^{\circ} \mathrm{C}$ using total ribonucleic acid (RNA) of leaf extracts; whereas a minimum of $20 \mathrm{ng} \mathrm{ll}^{-1}$ was required to detect CCCVd using conventional polymerase chain reaction (PCR). The utility of RT-LAMP as OS detection in plantations was evaluated using symptomatic and asymptomatic oil palm leaf samples from nurseries and field sites. RT-LAMP successfully detected CCCVd in OS-infected samples. Leaves with OS-like symptoms caused by nutrient deficiencies or leaf spot disease other than OS produced a negative result. The RT-LAMP results were confirmed by conventional PCR, indicating that RT-LAMP is a valuable tool, sensitive and rapid method of diagnosing OS in oil palm plantations that could be performed by plantation personnel for OS disease management in oil palm plantations.
\end{abstract}

Keywords: coconut cadang-cadang viroid (CCCVd) variants, loop-mediated isothermal amplification (LAMP), RT-LAMP, oil palm.

Date received: 25 July 2018; Sent for revision: 2 August 2018; Accepted: 11 October 2019; Available online: 27 August 2020.

\section{INTRODUCTION}

Palm oil produced by the oil palm (Elaeis guineensis) is one of the main commodities of Malaysia, which is one of the largest palm oil-producing countries in the world (Maizatul-Suriza, 2017). To date, Malaysia refined 13.35 million tonnes of crude palm oil and 3.32 million tonnes of palm kernels (MPOB, 2019). The high demand and the rapid growth of the oil

Malaysian Palm Oil Board,

6 Persiaran Institusi, Bandar Baru Bangi,

43000 Kajang, Selangor, Malaysia.

E-mail:madihah@mpob.gov.my palm industry have contributed to the distribution and rapid movement of pests and diseases from other counties (Idris et al., 2000). The existing pests, diseases and weeds pose a serious threat to oil palm plantations. However, in recent years, a disease known as orange spotting (OS) disease (also sometimes referred to as genetic orange spotting, GOS) has been identified in oil palm plantations (Vadamalai, 2005). OS is a major disease affecting the coconut industry, with total losses exceeding 40 million coconut palms in the Philippines (Randles and Rodriguez, 2003). To date, the incidence of OS disease in oil palm plantations has been low 
and, thus, has had little effect on palm oil yield (Sundram et al., 2017). Infected OS oil palms show stunted, often chlorotic, with yellowing or orange leaf spotting similar to that observed for coconut cadang-cadang viroid (CCCVd) disease in coconut palms. The discovery of some sequence variants of CCCVd in Malaysian oil palms has provided an important means of diagnosing the disease (Vadamalai et al., 2006) in oil palms given that there are variations between CCCVd in oil palms and coconuts.

The causal agent of OS disease is CCCVd variants. Viroids are the smallest known infectious pathogens and are composed of circular or linear single-stranded RNA. CCCVd ribonucleic acids (RNA) vary in size from 246 to 247 nucleotides in the early stages of infection and can extend to 296 to 297 nucleotides (Hanold and Randles, 1991; 2003), sometimes reaching 375 nucleotides during the late stages of infection. CCCVd variants can be detected using methods such as polyacrylamide gel electrophoresis (PAGE), ribonuclease protection assay (RPA), probe hybridisation and reverse transcription-polymerase chain reaction (RTPCR) (Thanarajoo et al., 2014); however, these techniques have low levels of accuracy and are time-consuming to perform. Nucleic acid-based detection is a method that can provide reliable and robust identification results. Reverse transcription loop-mediated isothermal amplification (RTLAMP) is a novel technique for nucleic acid amplification that amplifies deoxyribonucleic acid (DNA) and ribonucleic acid (RNA) with high levels of sensitivity, rapidity and specificity under isothermal conditions (Nimitphak et al., 2008), and can be performed using a heating block or even in an inexpensive water bath. Sensitivity of RTLAMP is 10-fold higher than conventional nested PCR (Gunimaladevi et al., 2005). In this study, we report the application of a RT-LAMP assay for rapid detection of CCCVd variants associated with OS disease in oil palm from nurseries and field sites.

\section{MATERIAL AND METHODS}

\section{Source of Viroids}

The RNA fragments of oil palm CCCVd KS1 (MF616386) was obtained in this study. The viroid was extracted from the CCCVd-infected oil palm leaves collected from the area that has been infected by OS disease, in Kuala Selangor, Selangor, Malaysia. RNA of other viroids were artificially synthesised due to unavailability of the viroids as some of them are exotic pathogens of Malaysia and could not be brought in due to quarantine issue. The RNA sequences were obtained from GenBank database as follow; oil palm CCCVd variant 270
$\left(\mathrm{CCCVd}_{270}, \mathrm{DQ} 097185,270 \mathrm{bp}\right)$; coconut CCCVd variant $246\left(\mathrm{CCCVd}_{246}, \mathrm{KM} 588102,246 \mathrm{bp}\right)$; oil palm CCCVd variant 293 (CCCVd ${ }_{293}$ DQ097184, $\left.293 \mathrm{bp}\right)$; oil palm CCCVd variant $297\left(\mathrm{CCCVd}_{297}\right.$, DQ097183, 297 bp); citrus exocortis viroid (CEV, S67442, 463 bp); coconut Tinangaja viroid (CTiVd, M20731, 254 bp); Hop latent viroid (HLVD, EF613192, 256 bp); eggplant latent viroid (ELVd, AJ536612, 335 bp); apple scar skin viroid (ASSVd, DQ362907, $331 \mathrm{bp}$ ); and peach latent mosaic viroid (PLMVd, JN680785, $302 \mathrm{bp}$ ). The RNA fragments were cloned into pMiniT vector (NEB, USA) and transformed into Escherichia coli $\mathrm{DH} 5 \alpha$. The transformants were cultured and maintained in Luria Bertani (LB) media at $37^{\circ} \mathrm{C}$ and stored in glycerol stock under $-80^{\circ} \mathrm{C}$ for longer storage. Plasmid was extracted using Monarch ${ }^{\circledast}$ Plasmid Miniprep kit (NEB, USA).

\section{Preparation of Leaf Samples}

The leaves were harvested early in the morning and placed in a cooler box to ensure freshness. The samples were processed on the same day as harvesting to preserve the RNA. The leaves were subjected to surface sterilisation to clean and discard dust and contaminants with $10 \%$ sodium hypochlorite, $70 \%$ ethanol and sterile distilled water, before being cryopreserved in liquid nitrogen to freeze and stored at $-80^{\circ} \mathrm{C}$ prior to RNA extraction.

\section{Total RNA Extraction}

RNA was extracted from the leaf samples using the cetyltrimethylammonium bromide (CTAB) method with some modifications (Zeng and Yang, 2002). The CTAB buffer (Sigma-Aldrich, St Louis, MO, USA) was heated at $65^{\circ} \mathrm{C}$ and stirred overnight before sterilisation at $121^{\circ} \mathrm{C}$ for 15 $\mathrm{min}$. The leaf was pulverised using a mortar and pestle in the presence of liquid nitrogen. A $2 \mathrm{~g}$ of ground sample was added to $20 \mathrm{ml}$ of extraction buffer [2\% CTAB buffer, polyvinylpyrrolidone (mol. wt 40 000) and spermidine trihydrochloride] (Sigma-Aldrich, St Louis, MO, USA) combined with $\beta$-mercaptoethanol (Invitrogen, Waltham, MA, USA). Final centrifugation was performed at $11000 \mathrm{rpm}$ for $30 \mathrm{~min}$ at $4^{\circ} \mathrm{C}$. The aqueous layer was carefully aspirated into new Falcon tubes before adding one-third volume $8 \mathrm{M} \mathrm{LiCl}$. Samples were stored overnight at $4^{\circ} \mathrm{C}$ and centrifuged the next day at $11000 \mathrm{rpm}$ for $45 \mathrm{~min}$ at $4^{\circ} \mathrm{C}$. The supernatants were discarded, and the pellets were washed with $75 \%$ ethanol three times. Tubes were centrifuged again at $11000 \mathrm{rpm}$ for $10 \mathrm{~min}$ at $4^{\circ} \mathrm{C}$ and the samples were air dried for $30 \mathrm{~min}$. The RNA pellets were dissolved in $50 \mu \mathrm{l}$ of diethylpyrocarbonate (DEPC)-treated water and stored at $-80^{\circ} \mathrm{C}$. The RNA concentration was determined using NanoDrop (Thermo Fisher Scientific, Waltham, MA, USA). 


\section{Phylogenetic Tree Analysis}

A phylogenetic tree was constructed using a viroid sequence isolated from oil palm leaves in this study (isolate KS1) and sequences of other viroids previously deposited in GenBank using the Maximum Likelihood Method. The evolutionary analyses were performed using MEGA7 (Kumar et al., 2016). A bootstrap analysis was performed using 1000 resampling of the data (Felsenstein, 1985) to provide statistical confidence values for the tree branches. The evolutionary distances were calculated using the Jukes-Cantor method (Jukes and Cantor, 1969).

\section{Primer Design}

The RT-LAMP primers were designed using PrimerExplorer V4 (https://primerexplorer.jp/e/). The following primers were used in this study (where $N$ represents a nucleotide consisting of ATCG bases; non-disclosure of CCCVd-specific primers prior to patent, patent file No. PI2017702332): forward outer primer, CCCVdFIP (5' GKS-N-N-NN-GT 3'); backward outer primer, CCCVdBIP (5' AAN-N-N-N-N-N-VS 3'); forward primer, CCCVdF3 (5' PSQIRL-N-N-N-N-N-N-KPLQER 3'); backward primer, CCCVdB3 (5' VRVGGDSP-N-N-N-N-N-SPK $\left.3^{\prime}\right)$. All primers were synthesised by Integrated DNA Technologies (IDT) (Singapore).

\section{RT-LAMP Reaction}

Assay was conducted using two RT-LAMP detection systems: turbidity and/or fluorescence. Turbidity measurement was carried out by detecting the cloudiness of magnesium pyrophosphate ions, which are a by-product of the DNA synthesis reaction (Mori et al., 2004) using a turbidimeter, ELIXA LoopAmp ${ }^{\circledR}$ Realtime Turbidimeter (Eiken, Tokyo, Japan). The following components were used in the RT-LAMP amplification: $2.5 \mu \mathrm{l}$ DNA/ RNA template (50-100 ng $\left.\mu \mathrm{l}^{-1}\right), 1.0 \mu \mathrm{l}$ enzyme mix (consists of reverse transcriptase and Bst polymerase), $12.5 \mu$ l reaction mix buffer (Eiken, Tokyo, Japan), $2.5 \mu$ l positive control (NEB, USA), $4 \mu \mathrm{l}$ nuclease-free water (Promega, Fitchburg, USA) and $1 \mu \mathrm{l}$ each of the four specific $10 \mathrm{mM}$ primers. Apart from the used of turbidity meter, a visual detection was also performed by adding $1.0 \mu \mathrm{l}$ dye (Loopamp $^{\circledR}$ Fluorescent Detection Reagent; Eiken, Tokyo, Japan) into the reaction mix. The addition of dye in the mixture provides colorimetric detection that turns reagent into green colour on positive samples. The remaining orange colour indicated no amplified product was detected. Fluorescence detection was carried out using isothermal Genie III machine (OptiGene, Horsham, UK) and evaluated by the presence of amplification curve and melting curve. The reaction mix was prepared using following components: $1 \mu \mathrm{l}$ DNA/RNA template (50-100 ng $\left.\mu \mathrm{l}^{-1}\right), \quad 12 \mu \mathrm{l}$ isothermal master mix (OptiGene, UK), $4 \mu$ l nuclease-free water (Promega, USA) and $3 \mu$ primers mix (IDT, Singapore). Both isothermal assays were performed using the following amplification programme: incubation at $63^{\circ} \mathrm{C}$ for $60 \mathrm{~min}$ and termination at $85^{\circ} \mathrm{C}$ for $5 \mathrm{~min}$ for RNA, or termination at $80^{\circ} \mathrm{C}$ for $2 \mathrm{~min}$ for DNA.

Specificity assay was done using CCCVd isolate KS1, CCCVd variant 270, CCCVd variant 246, CCCVd variant 293, CCCVd variant 297, CEVd, CTiVd, HLVD, ELVd, ASSVd and PLMVd using both systems. As control, plasmid pMiniT$\mathrm{CCCVd}_{246}$ with a double-stranded fragment of $\mathrm{CCCVd}_{246}$ was used. All RT-LAMP products were also analysed on $2 \%$ agarose gel electrophoresis at $90 \mathrm{~V}$ for $60 \mathrm{~min}$ and visualised under UV light transillumination using a BioImaging System (UVP, Upland, CA, USA). The amplified products were loaded along with a 1-kb DNA ladder (New England Biolabs, Ipswich, MA, USA) containing Redsafe staining solution (Intron Biotechnology, Kyungki-Do, Korea) in 1x Tris-acetate-EDTA (TAE) buffer (Thermo Fisher Scientific, Waltham, MA, USA). All assays were replicated in three separate experiments to confirm the accuracy of the results.

\section{Assay Sensitivity}

The sensitivity of the CCCVd RT-LAMP using the CCCVd primers was investigated using 10-fold serial dilutions (i.e. 2000, 200, 20 and $2 \mathrm{ng} \mu \mathrm{l}^{-1}$ ) of the RNA extracted from oil palm CCCVd KS1 as well as other viroids using fluorescence system. Amplification curves were plotted to show the rate of amplification using RT-LAMP at the different dilutions.

\section{PCR}

Detection was also compared via conventional PCR amplification using the primers CCCVdF3 and CCCVdB3. RNA was first converted into the first strand of complementary DNA using avian myeloblastosis virus reverse transcriptase (Promega, Fitchburg, WI, USA). Amplification was carried out using a commercial kit supplied by New England Biolabs (Ipswich, MA, USA) and using the following cycling programme: 35 cycles of denaturation at $94^{\circ} \mathrm{C}$ for $1 \mathrm{~min}$, annealing at $60^{\circ} \mathrm{C}$ for $30 \mathrm{~s}$ and elongation at $72^{\circ} \mathrm{C}$ for $5 \mathrm{~min}$ in a Vapo Protect thermal cycler (Eppendorf, Hamburg, Germany). All PCR products were analysed on $2 \%$ agarose gel electroporated at $90 \mathrm{~V}$ for $60 \mathrm{~min}$ and visualised under UV light transillumination using a BioImaging System (UVP, Upland, CA, USA). All the tests were replicated in three separate experiments. 


\section{Evaluation of RT-LAMP for Detection of CCCVd in Oil Palm}

The sample were collected from symptomatic and asymptomatic leaves of oil palms (Elaeis guineensis Jacq., dura x pisifera cultivar) growing in nurseries and field sites in Malaysia which had been screened for the presence of CCCVd in a previous study (Sundram et al., 2017).

The leaves from the nurseries were collected from oil palm seedlings that were at least three months old. The nurseries were located at Bangi, Selangor and Keratong, Pahang. The leaves from the field sites were collected from 17- to 25-year old mature oil palms growing at one location in Selangor (Kuala Selangor), two locations in Perak (Seberang Perak and Teluk Intan) and one location in Pahang (Keratong). The RT-LAMP reaction was carried out using turbidity meter and visual colorimetric assessment.

\section{Statistical Analysis}

Data were analysed using Statistical Analysis System (SAS) software (SAS Institute, Cary, NC, USA) and SigmaPlot (Systat Software, Incorporation, CA,
USA). Means were separated using Kruskal-Wallis one way analysis of variance (ANOVA) on ranks. All pairwise multiple comparison. Procedures were done using Student-Newman-Keuls Method. The alpha was at $\mathrm{P}=0.05$.

\section{RESULTS}

\section{Relationship between Oil Palm CCCVd and Other Viroids}

A phylogenetic tree was constructed using the oil palm CCCVd isolate KS1 (MF616386; boxed in red isolated in this study) CCCVd variants and other viroids (Figure 1). Isolate KS1 is closely related to the other CCCVd viroids, particularly viroids isolated from oil palm and coconut, with a shared sequence identity ranging from $65 \%-98 \%$. Analysis of the 10 other CCCVd variant and viroid sequences revealed no unique regions among them, which made designing an ideal target for specific detection of $\mathrm{CCCVd}_{246}$ using LAMP a challenge. As a result, the default programme in the LAMP Designer software produced only four instead of six primers for CCCVd detection using LAMP.

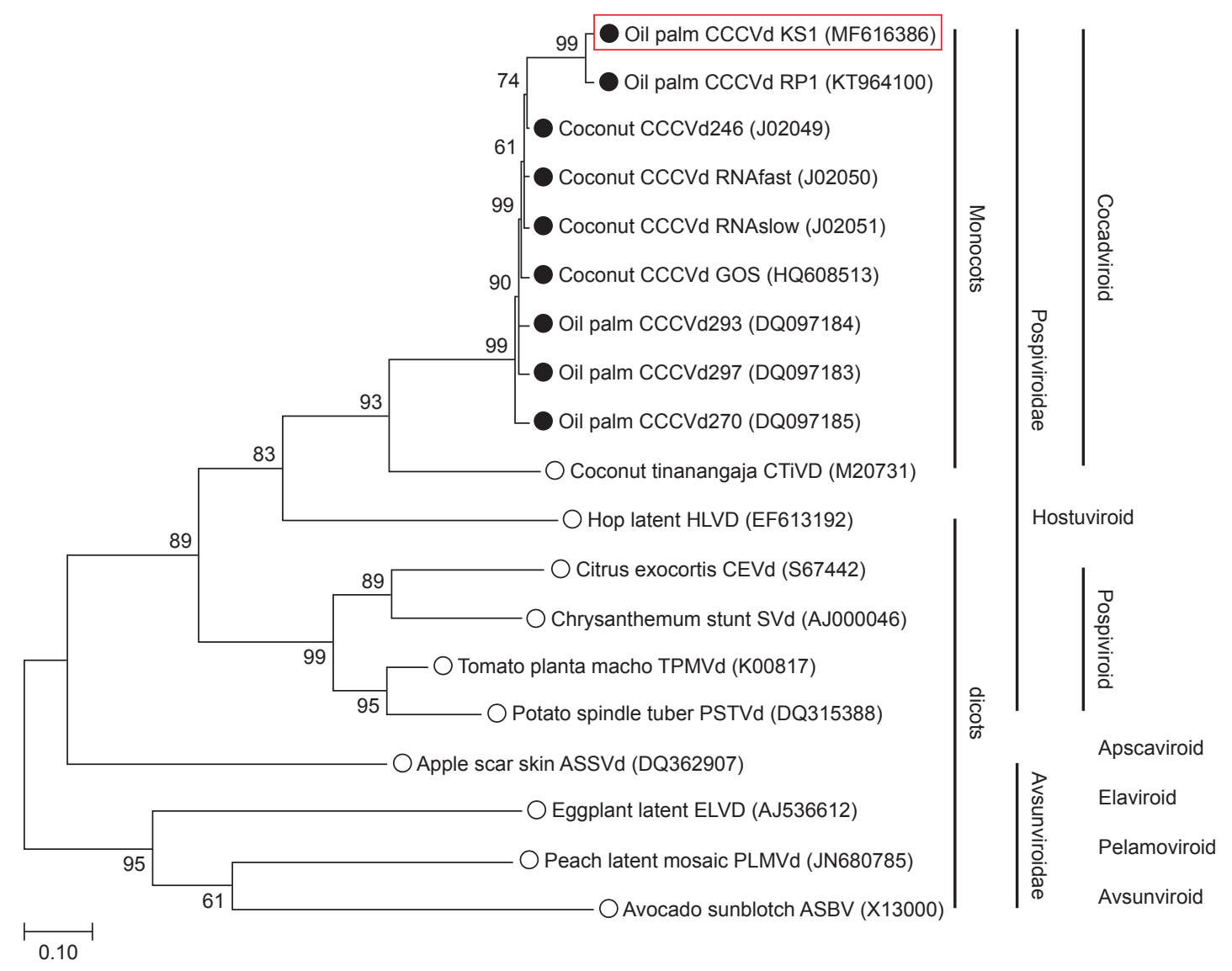

Figure 1. Phylogenetic tree of viroids and coconut cadang-cadang viroid (CCCVd) variants constructed with MEGA7 obtained automatically by applying the maximum likelihood method with 1000 bootstrap replicates modelled by Jukes-Cantor. The scale bar represents the sequence divergence. The isolate sequenced in this study is outlined with a red box, oil palm CCCVd isolate KS1. CCCVd variant KS1 is closely related to other CCCVd variants, particularly those isolated from oil palm and coconut. 


\section{Sensitivity of RT-LAMP}

Serial dilution of CCCVd plasmid scattered in the linear plot showed that using a smaller quantity of RNA template for detection achieved a greater sensitivity for the targeted products (Mori et al., 2004). The highest concentration of CCCVd

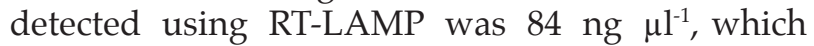
corresponded to $2.81 \times 10^{10}$ copies of CCCVd, and

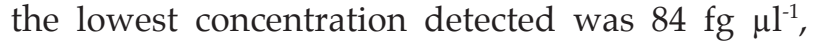
which corresponded to $2.81 \times 10^{4}$ copies of CCCVd RNA, from a dilution of $10^{\circ}$ and $10^{-5}$, respectively. The detection of amplified fragments peaked between 19.00 and $50.25 \mathrm{~min}$ of the RT-LAMP reaction (Figure 2).

Dilutions of DNA extracted from symptomatic and asymptomatic OS leaves were tested using RTLAMP and conventional PCR (Table 1). At dilutions of $10^{-2}, \mathrm{CCCVd}$ was detected in leaf extracts using both methods. However, at dilutions of $10^{-3}, \mathrm{CCCVd}$ was only detected in leaf extracts using RT-LAMP. The concentration of undiluted CCCVd RNA was 2 $\mu \mathrm{g} \mu \mathrm{l}^{-1}$ and in a $10^{-3}$ dilution it was $2 \mathrm{ng} \mu \mathrm{l}^{-1}$. However, PCR only amplified CCCVd at concentrations of

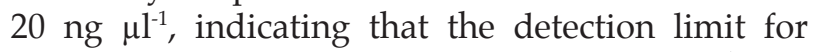
conventional amplification was 20-2000 ng $\mu^{-1}$. RTLAMP and conventional PCR appeared to have comparable sensitivity to detect CCCVd variants in the tissue extracts.

\section{Specificity of RT-LAMP}

The RT-LAMP primer specificity tests revealed that out of the 11 viroids tested, seven isolates (CCCVd KS1, CCCVd ${ }_{270}, \mathrm{CCCVd}_{246}, \mathrm{CCCVd}_{293}$, $\mathrm{CCCVd}_{2977}$ HLVD and ELVd) gave positive results when amplified with RT-LAMP, producing multiple bands. CEVd, CTiVd, PLMVd and ASSVd viroids were not amplified using RT-LAMP (Figure 3). The amplification products of RT-LAMP produced a ladder pattern, whereas a single band was observed for the amplification products of PCR (Parida et al., 2008). Like conventional PCR, the primers designed for RT-LAMP amplified the CCCVd region; however, unlike conventional PCR, the primers also amplified HLVD and ELVd (Table 1).

\section{OS Symptoms and RT-LAMP Detection of CCCVd in Nursery and Field Samples}

Mature oil palms in the field with OS showed a distinct discolouration of the crown; either orange, yellow or bronze, with or without severe desiccation of the lower fronds and $70 \%-80 \%$ of the old and middle fronds. The symptoms observed on the lower fronds spread to the younger fronds, so that eventually all the fronds were covered with orange spots. In the nurseries, irregular shaped orange spots were observed on oil palm seedlings;
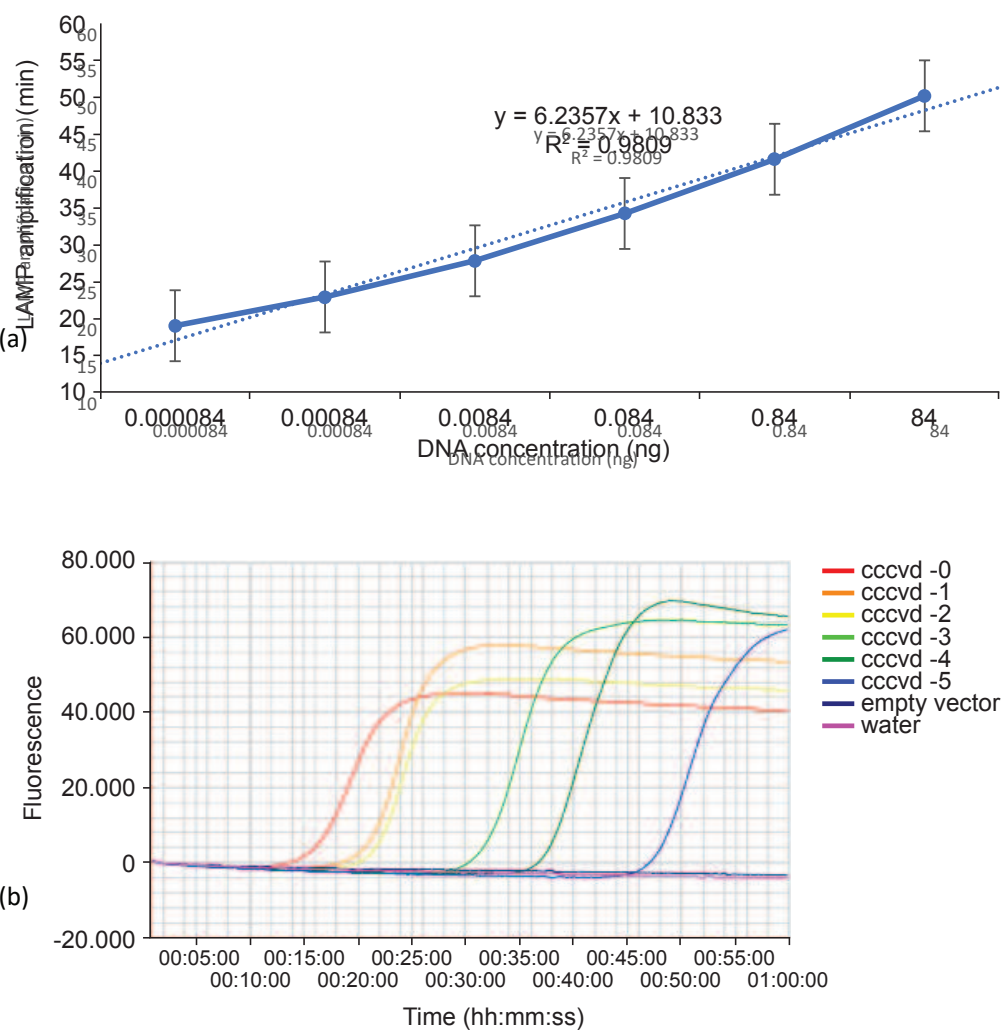

Figure 2. Reverse transcription loop-mediated isothermal amplification (RT-LAMP) sensitivity test: amplification speeds of CCCVd ${ }_{246} D N A$. (a) Standard curve of an amplification plot showing amplification time versus deoxyribonucleic acid (DNA) concentration (ng) in a serial dilution (10 to $10^{-5}$ ) of DNA. (b) Amplification curves of serial dilutions $\left(10^{\circ}\right.$ to $10^{-5}$ ) of the coconut cadang-cadang viroid (CCCVd) variant of oil palm. Sterile water (blank) and an empty vector (without CCCVd insert) represent negative controls. The amplification reaction was conducted within $60 \mathrm{~min}$ at $63^{\circ} \mathrm{C}$. 
TABLE 1. CCCVd VARIANTS AND VIROIDS USED TO EVALUATE THE SPECIFICITY AND SENSITIVITY OF RT-LAMP AND CONVENTIONAL POLYMERASE CHAIN REACTION (PCR)

\begin{tabular}{|c|c|c|c|c|c|c|c|c|c|c|c|}
\hline \multirow{4}{*}{$\begin{array}{c}\text { Viroid/ } \\
\text { variants }\end{array}$} & \multirow{4}{*}{$\begin{array}{l}\text { Accession } \\
\text { number }\end{array}$} & \multirow{4}{*}{ Host/origin } & \multirow{4}{*}{$\begin{array}{l}\text { Source of } \\
\text { RNA }\end{array}$} & \multicolumn{8}{|c|}{ Amplification/ Detection } \\
\hline & & & & \multicolumn{4}{|c|}{ RT-LAMP } & \multicolumn{4}{|c|}{ PCR } \\
\hline & & & & \multicolumn{8}{|c|}{ Concentration, $n g \mu \mathrm{l}^{-1}$ (dilution) } \\
\hline & & & & $\begin{array}{l}2000 \\
\left(10^{\circ}\right) \\
\end{array}$ & $\begin{array}{c}200 \\
\left(10^{-1}\right) \\
\end{array}$ & $\begin{array}{c}20 \\
\left(10^{-2}\right) \\
\end{array}$ & $\begin{array}{c}2 \\
\left(10^{-3}\right) \\
\end{array}$ & $\begin{array}{l}2000 \\
\left(10^{\circ}\right) \\
\end{array}$ & $\begin{array}{c}200 \\
\left(10^{-1}\right) \\
\end{array}$ & $\begin{array}{c}20 \\
\left(10^{-2}\right) \\
\end{array}$ & $\begin{array}{c}2 \\
\left(10^{-3}\right) \\
\end{array}$ \\
\hline CCCVd KS1 & MF616386 & Oil palm & Leaf extract & + & + & + & + & + & + & + & - \\
\hline $\mathrm{CCCVd}_{246}$ & KT964100 & Oil palm & Plasmid & + & + & + & + & + & + & + & + \\
\hline $\mathrm{CCCVd}_{270}$ & DQ097185 & Oil palm & Plasmid & + & + & + & + & + & + & + & + \\
\hline $\mathrm{CCCVd}_{246}$ & KM588102 & Coconut & Plasmid & + & + & + & + & + & + & + & + \\
\hline $\mathrm{CCCVd}_{293}$ & DQ097184 & Oil palm & Plasmid & + & + & + & + & + & + & + & + \\
\hline $\mathrm{CCCVd}_{297}$ & DQ097183 & Oil palm & Plasmid & + & + & + & + & + & + & + & + \\
\hline CEVd & S67442 & Citrus & Plasmid & - & - & - & - & - & - & - & - \\
\hline CTiVd & M20731 & Coconut tinangaja & Plasmid & - & - & - & - & - & - & - & - \\
\hline HLVD & EF613192 & Hop & Plasmid & + & + & + & + & - & - & - & - \\
\hline ELVd & AJ536612 & Egg plant & Plasmid & + & + & + & + & - & - & - & - \\
\hline ASSVd & DQ362907 & Apple & Plasmid & - & - & - & - & - & - & - & - \\
\hline PLMVd & JN680785 & Peach & Plasmid & - & - & - & - & - & - & - & - \\
\hline
\end{tabular}

Note: The reaction was performed in $60 \mathrm{~min}$ at $63^{\circ} \mathrm{C}$ and analysed on $2 \%$ agarose gel. The ' + ' and ' - ' symbols denote successful amplification and no amplification, respectively (indicating that the sample tested positive or negative for CCCVd, respectively).

CCCVd - coconut cadang-cadang viroid.

RT-LAMP - reverse transcription loop-mediated isothermal amplification.

RNA - ribonucleic acid.

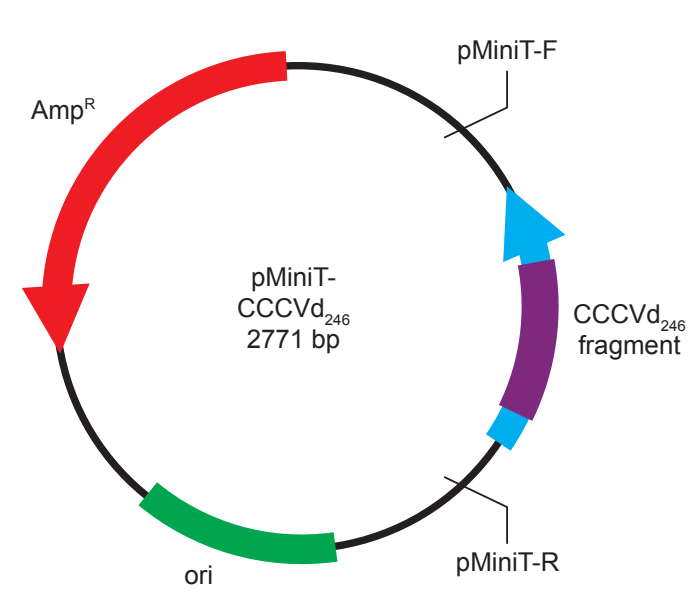

(a)

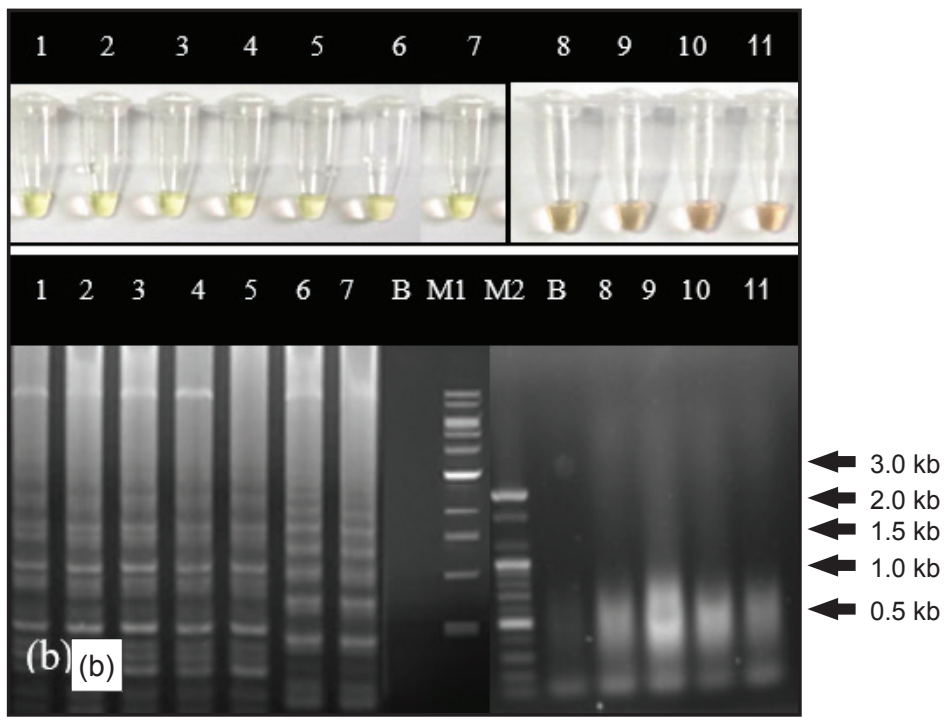

Figure 3. Reverse transcription loop-mediated isothermal amplification (RT-LAMP) specificity assay. (a) Construction of a plasmid pMiniT-CCCVd ${ }_{246}$ with double-stranded CCCVd ${ }_{246}$ cloned into a plasmid pMiniT as a positive control. (b) Separation of RT-LAMP products of coconut cadang-cadang viroid (CCCVd) variants and other viroids using 2\% agarose gel electrophoresis. Lane 1 - CCCVd isolate KS1; lane $2-C C C V d_{270^{\prime}}{\text { lane } 3-C C C V d_{246^{\circ}}}_{3}$ lane 4 - CCCVd 293 ; lane 5 - CCCVd 297 ; lane 6 - HLVD; lane 7 - ELVd; lane 8 - CEVd; lane 9 - CTiVD; lane 10 - ASSVd; lane 11 - PLMVd; lane B - negative control; lane M1 - 1 kb DNA ladder (NEB, MA, USA); M2 - 100 bp DNA ladder (Bioneer, Daejeon, Korea). The reagent colour changed from orange to yellow-green in microcentrifuge tubes 1-7 indicates a positive reaction, i.e. the amplification of CCCVd variants or a CCCVd-like viroid. 
however, the density of the spots was lower than that observed on the mature oil palm leaves in the field. The lower or older fronds of severely diseased seedlings were desiccated; this was most commonly observed in 5- to 10-year old palms.

Positive detection of CCCVd from the symptomatic OS leaves was indicated by colour changes from orange to green (Figure 4) and the production of sigmoid amplification curves (data not shown) with the differential factor (Df) value of $>0.1$ (Parida et al., 2008). By contrast, the absence of CCCVd from asymptomatic leaf was indicated by the Df value below 0.1, without sigmoid curve and orange colour (no colour changes).
RT-LAMP was able to detect CCCVd variants in all the symptomatic OS leaves collected from field sites in Kuala Selangor in Selangor (Table 2). The CCCVd variants were detected in only $40 \%$ of the symptomatic OS leaves collected from field sites in Seberang Perak and Teluk Intan in Perak indicating that the distribution of the OS disease at these sites was moderate. Amplification with PCR produced similar findings. The amplification products on $2 \%$ agarose gel produced a ladderlike structure with DNA smeared on the gel with sizes ranging from 150-2000 bp, with the bands above $10 \mathrm{~kb}$ indicating an excess of DNA template.
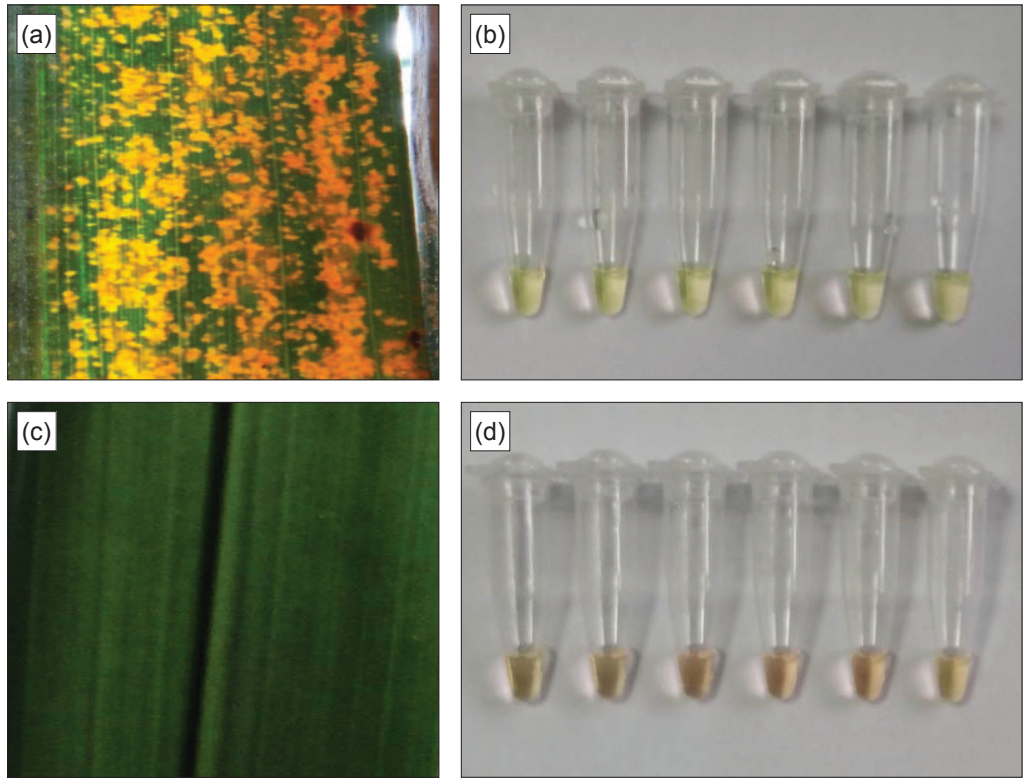

Figure 4. Reverse transcription loop-mediated isothermal amplification (RT-LAMP) detection of coconut cadang-cadang viroid (CCCVd) variants on oil palm leaves measured by colorimetric change. The orange spotting on a leaf (a) showed a positive result using RT-LAMP, producing changes of reagent colour from orange to yellow-green (b). Healthy-looking or asymptomatic leaf (c), which showed a negative result using RT-LAMP with the reagent colour remained orange (d).

TABLE 2. DETECTION OF CCCVd VARIANTS USING RT-LAMP IN OIL PALM LEAF SAMPLES FROM NURSERIES AND FIELD SITES SHOWING SYMPTOMS OF ORANGE SPOTTING AND ASYMPTOMATIC LEAVES

\begin{tabular}{|c|c|c|c|c|}
\hline Leaf sample & $\begin{array}{l}\text { Sampling } \\
\text { sites, state }\end{array}$ & $\begin{array}{l}\text { Number of } \\
\text { samples }\end{array}$ & $\begin{array}{l}\text { Positive detection } \\
\text { of CCCVd }(\%)\end{array}$ & Remarks \\
\hline \multirow{4}{*}{$\begin{array}{l}\text { Mature oil palm } \\
\text { in the field }\end{array}$} & Kuala Selangor, Selangor & 18 & $100.00^{\mathrm{a}}$ & Palms with symptomatic orange spotting \\
\hline & Seberang Perak, Perak & 18 & $38.89^{b}$ & $\begin{array}{l}\text { Palms with symptomatic orange spotting, leaf } \\
\text { spot disease and nutrient deficiencies }\end{array}$ \\
\hline & Teluk Intan, Perak & 18 & $38.89^{b}$ & $\begin{array}{l}\text { Palms with symptomatic orange spotting, leaf } \\
\text { spot disease and nutrient deficiencies }\end{array}$ \\
\hline & Keratong, Pahang & 18 & $5.56^{c}$ & $\begin{array}{l}\text { Palms with asymptomatic orange spotting, leaf } \\
\text { spot disease and nutrient deficiencies }\end{array}$ \\
\hline \multirow{2}{*}{$\begin{array}{l}\text { Oil palm } \\
\text { seedlings } \\
\text { in nurseries }\end{array}$} & Bangi, Selangor & 18 & $0.00^{c}$ & $\begin{array}{l}\text { Seedlings with asymptomatic orange spotting, } \\
\text { leaf spot disease and nutrient deficiencies }\end{array}$ \\
\hline & Keratong, Pahang & 18 & $0.00^{c}$ & $\begin{array}{l}\text { Seedlings with asymptomatic orange spotting, } \\
\text { leaf spot disease and nutrient deficiencies }\end{array}$ \\
\hline
\end{tabular}

Note: *Values are mean of three replicates and values with the same letter in the same column are not significant based on Kruskal-Wallis one way analysis of variance (ANOVA) on ranks. All pairwise multiple comparison procedures were done using Student-Newman-Keuls Method at at $\mathrm{P}=0.05$.

CCCVd - coconut cadang-cadang viroid.

RT-LAMP - reverse transcription loop-mediated isothermal amplification. 


\section{DISCUSSION}

In this study, different RNA extraction method was used following Zeng and Yang (2002) with modifications. Based on our experience, RNA extracted from this method produce better yield and quality as compared to using natrium chloride EDTA Tris-HCI Mercaptoethanol (NETME) extraction (Thanarajoo et al., 2014). They designed the primers based on the 297-nucleotide (nt) of oil palm CCCVd. The primers in our study was designed based on different RNA fragment of 246-nt of CCCVd.

Overall, three systems (turbidity, colorimetric and fluorescent) were used as detection. Reagents used were from Eiken (Japan) and Optigene (UK). Detection was conducted with Loopamp machine (Eiken, Japan) which measured the turbidity of the by-product of LAMP and/or Genie III (Optigene, UK) which detected the fluorescence. Reagent combined with dye provided colorimetric detection solely based on colour changes of the dye. Colorimetric dye was also incorporated in our assays on top of these. Colorimetric changes although useful, can only provide qualitative results (negative or positive). Detection using turbidity meter provided greater finding with semiquantitative data. The use of fluorescence detection system however, is more quantitative. The same principal was used in detection of qPCR. We also used the fluorescence system to study the sensitivity of the RT-LAMP and to develop quantification using LAMP (qLAMP). LAMP detection system from Optigene (reagents combined with Genie III instrument) provide melt curve analysis that can be used to distinguish false positive.

Phylogenetic tree analysis was performed to study the ancestral relationship between oil palm, coconut and other viroids. The phylogenetic tree, which was constructed using sequences of oil palm CCCVd isolate KS1 and other CCCVd variants, demonstrated that CCCVd variants from coconut and oil palm are grouped in the same family, Pospiviroidae, and belong to the Cocadviroid genus, which infects monocots. The oil palm CCCVd variant isolated in this study (CCCVd isolate KS1, boxed in red in Figure 1; MF616386) was closely related to CCCVd isolate RP1 (KT964100), which was isolated from oil palm in a previous study (Roslan et al., 2016), because they were clustered in the same clade on the phylogenetic tree and shared $98 \%$ sequence identity. The other seven CCCVd variants deposited in GenBank [i.e. CCCVd RNA (fast and slow)], $\mathrm{CCCVd}_{246}, \mathrm{CCCVd}_{293}, \mathrm{CCCVd}_{270}, \mathrm{CCCVd}_{297}$ and CCCVd GOS) formed a separate clade.

There are few base pair differences between the sequences of CCCVd KS1 and the other CCCVd variants and, hence, developing primers that could distinguish between these variants and viroids was a challenge. The high occurrence of substitutions and deletions has produced many variations both in oil palm and coconut. The variations between monocots infected by the genus Cocadviroid are considered unique based on the similar base substitutions in oil palm sequences with the conversion of cytosine $(C)$ to guanine $(G)$ or uracil (U) to adenine (A): for example, C70 $\rightarrow \mathrm{G}$, $\mathrm{U} 98 \rightarrow \mathrm{A}$, $\mathrm{G} 99 \rightarrow \mathrm{C}, \mathrm{G} 100 \rightarrow \mathrm{C}, \mathrm{G} 101 \rightarrow \mathrm{C}, \mathrm{C} 103 \rightarrow \mathrm{G}, \mathrm{G} 104 \rightarrow \mathrm{C}$ and $\mathrm{C} 140 \rightarrow \mathrm{A}$, which was reported by Roslan et al. (2016). In another study, base substitutions of $\mathrm{C} 31 \rightarrow \mathrm{U}, \mathrm{G} 70 \rightarrow \mathrm{C}$ and $\mathrm{C} 140 \rightarrow$ A were reported in oil palm from field samples, early germinated plants and plantlets (Hendry, 2012). A study also found the same base substitution of $\mathrm{C} 31 \rightarrow \mathrm{U}, \mathrm{G} 70 \rightarrow \mathrm{C}$, with an additional $\mathrm{A} 7 \rightarrow \mathrm{G}$ and $\mathrm{C} 242 \rightarrow \mathrm{U}$ in the sequence of the 246-nt oil palm CCCVd variant compared with the conserved sequence of the 246-nt coconut CCCVd variant (Wu et al., 2013). In asymptomatic oil palm, substitution has also been found at $\mathrm{C} 31 \rightarrow \mathrm{U}$ in the pathogenic region (P). Substitution of single bases or some bases could potentially increase the virulence of the CCCVd variants (Flores et al., 2005). The sequence variances shown in the phylogenetic tree are supported by a high bootstrap value, providing confidence that these organisms fall into the assigned group.

Optimisation of the RT-LAMP conditions, such as the amplification temperature and the design of the primer set, is crucial to ensure the success of the assay. When the constant temperature was initially set to $63^{\circ} \mathrm{C}$ (ranging from $60^{\circ} \mathrm{C}$ to $65^{\circ} \mathrm{C}$ ), all CCCVd variants were amplified, produced intact and clearer multiple bands. This may be because the high $\mathrm{A} / \mathrm{T}$ content in the primers reduces the annealing temperature to balance the oligonucleotide composition (Gao et al., 2016). Amplification was achieved in $60 \mathrm{~min}$. However, we managed to design only four RT-LAMP primers for the detection of the target sequence because of the constraint of short sequence of the viroid with only $246 \mathrm{bp}$. We have to omit the use of loop primers. Owing to the lack of loop primers, detection took longer than it would have with loop primers as these can reduce the amplification time to half that of the original LAMP (Nagamine et al., 2002).

The sensitivity of the RT-LAMP method is crucial for real time detection. RT-LAMP showed the amplification of CCCVd RNA happened at concentrations from $84 \mathrm{ng}$ to $84 \mathrm{fg}$ within $19 \mathrm{~min}$ to $50.25 \mathrm{~min}$, respectively (Figure 2). In other study done by Tomlinson et al. (2010), it showed that Botrytis cinerea was detected more fast and sensitive at a concentration of $6.5 \mathrm{pg}$ in $12 \mathrm{~min}$, compared to our study at $8.4 \mathrm{pg}$ in $35.25 \mathrm{~min}$. Detection limit for the CCCVd variants was at 2 to $2000 \mathrm{ng}$ in leaves. Study by Gao et al. (2016) showed better detection of Tilletia indica in sugar-cane with more than 10 pg (0.01 ng) of DNA. However, our result was comparable with a detection limit of $1 \mathrm{ng}$ within 40 
min as reported for Ophiostoma clavatum, a fungus associated with the insect, Ips acuminatus (Villari et al., 2013). Detection of CCCVd is a challenge because of the low concentration of CCCVd RNA presence in oil palm (Vadamalai et al., 2006). RTLAMP provides faster and more sensitive detection because of the titre of CCCVd viroid in the samples was very low compared to fungi and other pathogens. The CCCVd in this study is hardly to be found in the environment, less concentration with OS disease only appeared in isolated cases. Based on our experience, it is very hard to get high yield of CCCVd's RNA (total RNA extracted from CCCVd lots more lesser oil palm tissue).

Amplification specificity was achieved using both RT-LAMP and conventional PCR. Initially, the specificity test was carried out using Eiken (Japan), however, results showed that the Eiken reagent was unable to pick up lesser concentration of CCCVd, thus, not sensitive enough to conduct the test. In addition, reagent OptiGene (UK) provided more subtle response towards CCCVd and results proved that it can detect CCCVd using diluted template, yet sensitive.

We tested our RT-LAMP using RNA from 12 viroids and viroid variants: CCCVd KS1, CCCVd $\mathrm{CCCVd}_{270}, \mathrm{CCCVd}_{246,}, \mathrm{CCCVd}_{293}, \mathrm{CCCVd}_{297}, \mathrm{CEVd}$, CTiVd, HLVD, ELVd, ASSVd and PLMVd. Meanwhile, in Thanarajoo et al. (2014), detection was conducted in a heat block and specificity test was performed for CCCVd, PSTVd, and CEVd. Conventional PCR amplified the target fragment of approximately $\leq 200 \mathrm{bp}$, which was visualised as one intact band in the agarose gel (data not shown). RTLAMP products are detected as a ladder-like pattern of multiple bands of DNA on the electrophoresis agarose gel because of the many inverted repeats of stem loop DNA, which form cauliflower-like DNA structures (Villari et al., 2013) (Figure 3b). The CCCVd variants $\left(\mathrm{CCCVd}_{270^{\prime}} \mathrm{CCCVd}_{246^{\prime}} \mathrm{CCCVd}_{293^{\prime}}\right.$ $\left.\mathrm{CCCVd}_{297}\right)$, which were isolated from oil palm and coconut, and the viroids HLVD, which was isolated from hops, and ELVd, which was isolated from eggplant, were detected using RT-LAMP (Figure 3 and Table 1), indicating that the detection is a semispecific since the primers used in this study were also able to amplify certain regions in these viroids. However, the primers did not target any fragment of CCCVd in the other viroids (i.e. CEVd, CTiVd, ASSVd and PLMVd), possibly owing to unspecific binding and sequence differences in these viroids. Detection and each positive sample were confirmed by sequencing. We strongly believe, although our work somewhat similar with Thanarajoo et al. (2014), many advancements had been made.

A total of 88 samples of symptomatic and asymptomatic leaves from the oil palm seedlings growing in nurseries and mature oil palms (different stages of age and locations) in the field were evaluated using RT-LAMP. Our results suggest that the oil palm plantations in Kuala Selangor are severely infected with CCCVd variants given that CCCVd was detected in all the symptomatic leaf samples, whereas in Seberang Perak and Teluk Intan in Perak, less than $40 \%$ of the leaves were infected with CCCVd. Nutrient deficiencies and leaf spot disease were thought to explain the spotting observed on $60 \%$ of the symptomatic leaves (Sundram et al., 2017). Leaf spot disease is commonly recorded in the nursery: symptoms include the presence of double rings on the leaf that slowly coalesce and become less distinct, surrounded by orange or yellow smearing. Generally, the OS incidence in Perak was assumed to be under control as no severely infected palms were observed during the field inspection. Furthermore, Keratong, Pahang was perceived to be free from OS disease as no CCCVd variants were detected by RT-LAMP. The seedlings in Bangi (Selangor) and Keratong (Pahang) nurseries were thought to be infected with leaf spot disease or nutrient deficient based on the leaf criteria and the negative test result for CCCVd using RT-LAMP. In nurseries, nutrients commonly found deficient in oil palm seedlings are nitrogen, phosphorus, potassium, magnesium, boron, copper or zinc. Nutrient deficiencies can occur owing to insufficient nutrient applications, waterlogging, soil erosion or competition with weeds (Von Uexküll and Fairhurst, 1999).

In summary, the RT-LAMP assay developed in this study provided a sensitive detection method comparable with conventional PCR. The detection of CCCVd variants in oil palm leaves using RT-LAMP reduced the diagnostic time and avoided cross contamination between samples and the generation of false-positives. RT-LAMP can be performed at a single temperature with a short incubation time, and can be used for screening large sample sizes, either in the laboratory or the field. The colour change criteria of the RT-LAMP assay represent another advantage of RT-LAMP for screening purposes in the field. RTLAMP provides a simplified and robust method for detecting CCCVd variants that should enable the oil palm industry and quarantine agencies to screen and monitor the spread of the disease. To date, OS caused by CCCVd variants has not resulted in oil palm mortality. Nevertheless, the development of RT-LAMP detection may provide an opportunity to safeguard the palm oil industry.

\section{ACKNOWLEDGEMENT}

The authors are grateful to the Director-General of MPOB for permission to publish this article. The authors also thank the staff of MPOB for assistance and guidance in conducting this study. This work was supported by MPOB [RB009411000 / BD6-2.2.2]. 


\section{REFERENCES}

Felsenstein, J (1985). Confidence limits on phylogenies: An approach using the bootstrap. Evolution, 39(4): 783-791.

Flores, R; Hernández, C; De Alba, A E M; Daros J-A and Di Serio, F (2005). Viroids and viroid-host interactions. Annual Reviews Phytopathology, 43: 117139.

Gao, Y; Tan, M K and Zhu, Y G (2016). Rapid and specific detection of Tilletia indica using loopmediated isothermal DNA amplification. Australasian Plant Pathology, 45: 361-367. DOI 10.1007/s13313-0160422-7.

Gunimaladevi, I; Kono, T; Lapatra, S E and Sakai, M (2005). A loop mediated isothermal amplification (LAMP) method for detection of infectious hematopoietic necrosis virus (IHNV) in rainbow trout (Oncorhynchus mykiss). Archives of Virology, 150: 899-909. DOI:10.1007/s00705-0040468-7.

Hanold, D and Randles, J W (1991). Detection of coconut cadang-cadang viroid-like sequences in oil and coconut palm and other monocotyledons in the south-west Pacific. Annals of Applied Biology, 118: 139151.

Hanold, D and Randles, J W (2003). Chapter 54 Part VII: CCCVd-related molecules in oil palms, coconut palms and other monocotyledons outside the Philippines. Viroids (Hadidi, A; Flores, R; Randles, J W and Semancik, J S eds.). CSIRO Publishing, Collingwood, Australia. p. 336-340.

Hendry, J (2012). Characterization and Pathogenicity of Coconut Cadang Cadang Viroid Variants in Oil Palm (Elaeis guineensis Jacq.) seedlings. Ph.D thesis. Universiti Putra Malaysia, Serdang, Selangor, Malaysia. 171 pp.

Idris, A S; Ariffin, D; Swinburne, T R and Watt, T A (2000). The identity of Ganoderma species responsible for BSR disease of oil palm in Malaysia - Morphological characteristics. MPOB Information Series No. 77a: 4 pp.

Jukes, T H and Cantor, C R (1969). Evolution of protein molecules. Mammalia Protein Metabolism (Munro, H N ed.). Academic Press, New York, USA. p. 21-132.

Kumar, S; Stecher, G and Tamura, K (2016). MEGA7: Molecular evolutionary genetics analysis version 7.0 for bigger datasets. Molecular Evolutionary Genetics Analysis, 33(7): 1870-1874. DOI:10.1093/molbev/ msw054.
Maizatul-Suriza, M (2017). Phytophthora palmivora, the Causal Agent of Bud Rot Disease of Oil Palm (Elaeis guineensis Jacq.): Biology, Detection and Control. Ph.D thesis. University of Nottingham, Loughborough, United Kingdom. 283 pp.

MPOB (2019). Monthly production of oil palm products summary for the month of August 2019 (2018-2019). http:/ / bepi.mpob.gov.my/index.php/ en / statistics / production / 368-production-2019/ 905-production-of-oil-palm-products-2019.html, accessed on 4 October 2019.

Mori, Y; Kitao, M; Tomita, N and Notomi, T (2004). Real-time turbidimetry of LAMP reaction for quantifying template DNA. J. Biochemical and Biophysical Methods, 59: 145-157. DOI:10.1016/j. jbbm.2003.12.005.

Nagamine, K; Hase, $\mathrm{T}$ and Notomi, T (2002). Accelerated reaction by loop-mediated isothermal amplication using loop primers. Molecular and Cellular Probes, 16: 223-229. DOI:10.1006/ mcpr.2002.0415.

Nimitphak, T; Kiatpathomchai, W and Flegel, T W (2008). Shrimp hepatopancreatic parvovirus detection by combining loop-mediated isothermal amplification with a lateral flow dipstick. J. Virological Methods, 154: 56-60. DOI:10.1016/j. jviromet.2008.09.003.

Parida, M; Sannarangaiah, S; Dash, P K; Rao, P V L and Morita, K (2008). Loop mediated isothermal amplification (LAMP): A new generation of innovative gene amplification technique; perspectives in clinical diagnosis of infectious diseases. Reviews in Medical Virology, 18: 407-421. DOI: 10.1002 / rmv.593.

Randles, J W and Rodriguez, M J B (2003). Coconut cadang-cadang viroid. Viroids (Hadidi, A; Flores, R; Randles, J W and Semancik, J S eds.). CSIRO, Australia. p. 233-41.

Roslan, N D; Meilina, O A; Mohamed-Azni, I-NA; Idris, A S and Sundram, S (2016). Comparison of RNA extraction methods for RT-PCR detection of Coconut cadang-cadang viroid variant in orange spotting oil palm leaves. Canadian J. Plant Pathology: 7. DOI.org/10.1080/07060661.2016.1216013.

Sundram, S; Norman, K; Roslan, N D; Ramachandran, V; Idris, A S and Kushairi, A (2017). Orange Spotting on Oil Palm in Malaysia. MPOB, Bangi. 15 pp.

Thanarajoo, S S; Kong, L L; Kadir, J; Lau, W H and Vadamalai, G (2014). Detection of Coconut 
cadang-cadang viroid (CCCVd) in oil palm by reverse transcription loop-mediated isothermal amplification (RT-LAMP). J. Virological Methods, 202: 19-23. DOI.org/10.1016/j.jviromet.2014.02.024.

Tomlinson, J A; Boonham, $\mathrm{N}$ and Dickinson, M (2010). Development and evaluation of a one-hour DNA extraction and loop-mediated isothermal amplification assay for rapid detection of phytoplasmas. Plant Pathology, 59: 465-471. DOI: 10.1111/j.1365-3059.2009.02233.x.

Von Uexküll, H R and Fairhurst, T H (1999). Some nutritional disorders in oil palm. Better Crop International, 13(1): 16-21.

Vadamalai, G (2005). An Investigation of Orange Spotting Disorder in Oil Palm. Ph.D thesis. University of Adelaide, South Australia, Australia. 210 pp.

Vadamalai, G; Hanold, D; Rezaian, M A and Randles, J W (2006). Variants of Coconut cadangcadang viroid isolated from an African oil palm
(Elaies guineensis Jacq.) in Malaysia. Archives of Virology, 151: 1447-1456. DOI 10.1007/s00705-0050710-y.

Villari, C; Tomlinson, J A; Battisti, A; Boonham, N; Capretti, P and Faccoli, M (2013). Use of loopmediated isothermal amplification for detection of Ophiostoma clavatum, the primary blue stain fungus associated with Ips acuminatus. Applied and Environmental Microbiology, 79(8): 2527-2533. DOI:10.1128/ AEM.03612-12.

Wu, Y H; Cheong, L C; Meon, S; Lau, W H; Kong, L L; Joseph, H and Vadamalai, G (2013). Characterization of coconut cadang-cadang viroid variants from oil palm affected by orange spotting disease in Malaysia. Archives of Virology, 158: 140710. DOI 10.1007/ s00705-013-1624-8.

Zeng, Y and Yang, T (2002). RNA isolation from highly viscous samples rich in polyphenols and polysaccharides. Plant Molecular Biology Report, 20: 417a-417e. 